\title{
Socio-technical Change and the Politics of Urban Infrastructure: Managing Energy in Berlin between Dictatorship and Democracy
}

\author{
Timothy Moss
}

[Paper first received, May 2011; in final form, April 2012]

\begin{abstract}
This paper reconstructs the trajectory of energy efficiency policies in Berlin from the 1920s to today in order to illustrate how the shifting political and socioeconomic conditions of a city can shape urban energy provision and consumption. Taking a long-term perspective on the relationship between urban transitions and energy policy, it investigates how the geo-political turbulence, regime diversity and socioeconomic volatility experienced by 20 th-century Berlin influenced strategies of electricity generation and use in the city. Drawing on different ways of conceptualising change to socio-technical systems in the literature, the paper's findings present a more differentiated picture of urban energy transitions than notions of path dependency and transition pathways imply, highlighting the importance of non-linear trends, political contestation and crisis discourses in and beyond the city and their relevance for reconfiguring urban energy systems today.
\end{abstract}

Keywords: Berlin, energy transitions, socio-technical change, urban infrastructure

\section{Introduction}

The shift to a low-carbon society has become a clarion call for decision-makers across the globe. Whether to combat climate change, peak oil, energy insecurity or rising energy prices, the new policy paradigm is for a world which is energy efficient and independent of fossil fuels. Experiences in pursuing this policy goal suggest that the notion of changing track from a fossil-based to a post-fossil economy

Timothy Moss is in the Leibniz Institute for Regional Development and Structural Planning (IRS), Flakenstraße 28-31, Erkner 15537, Germany. Email: mosst@irs-net.de. 
is grossly simplistic. Energy transitions are, in practice, highly complex, non-linear, contested and spatially diverse phenomena requiring a sound understanding of the structures and dynamics which shape systems of energy provision and use. Scholars have made significant contributions to deconstructing oversimplistic notions of energy transitions. Three of these-relating to the importance of socio-technical systems, cities and historical experience-are central to this paper. Firstly, changes to energy provision and use are understood not simply as the application of a new technology, but as a reordering of the multiple political, organisational, financial, material and cultural components which constitute a sociotechnical system for energy (Summerton, 1994; Star, 1999). Secondly, cities are today widely acknowledged as important loci of (future) energy consumption and key players of energy and climate change policy, generating keen interest in the relationship between socio-technical and urban transitions (Bulkeley and Betsill, 2003; McFarlane and Rutherford, 2008; Hodson and Marvin, 2010a, 2010b; Bulkeley et al., 2011b). Thirdly, research into the historical development of our (urban) energy systems has revealed the importance of path dependencies, discarded alternatives and contingency in forming today's socio-technical systems (Tarr, 1979; Hughes, 1983; Tarr and Dupuy, 1988; Melosi, 2000).

Much of this literature is targeted at explaining how energy systems change, over time and in specific contexts (see section 2). The focus is on specific energy transitions: how they emerge, are promoted or constrained in urban contexts. Conversely, this paper looks at urban transitions and how they influence energy policy. Taking the city of Berlin as an example, it poses the key question: how did the geo-political turbulence, regime diversity and socioeconomic volatility experienced by 20th-century Berlin influence strategies of electricity generation and use in the city? The paper investigates what changed-and what did not change-in the city's energy policy as a result of radical and repeated re-ordering of its political economy. It explores how energy policy in general-and energy efficiency in particular-was enrolled to protect the city's diverse political systems and respond to socioeconomic shifts. It seeks to illustrate, further, how the 'urban' of Berlin's energy policies was bound up in wider national and international geo-political contexts.

Rather than focus on a particular energy technology or socio-technical innovation introduced at one point in time, the paper investigates energy efficiency as a more suitable issue for revealing shifts and continuities in energy policy over a long period. It explores in particular the underlying tension between the efficient use of energy resources on the one hand and the efficient use of energy infrastructures on the other, demonstrating when and why energy efficiency was taken up (and discarded) as a policy priority.

The case for selecting Berlin is essentially two-fold. Firstly, Berlin had by the 1930s come to symbolise the networked city of Europe. By virtue of its huge electrical industry Berlin became known as the 'Elektropolis' (Hughes, 1983, p. 177), representing a model of urban modernity. Secondly, in the course of the 20th century, Berlin came to represent less a model than an exceptional case, characterised by radical political ruptures and multiple crises. Each of these crises-whether the Depression, the Nazi seizure of power, wartime destruction or political division into East and West Berlin and subsequent reunification-had a far-reaching impact on the city's energy systems (for historical overviews see Bewag, 1984; Varchmin and Schubert, 1988). Exploring how infrastructure 
systems-generally renowned for their inherent stability and path dependencywere affected by the political turbulence and diversity of 20th-century Berlin throws into sharp relief attributes and dynamics of these socio-technical systems often hidden in other cities by the patina of familiarity (see Summerton, 1994).

In line with the other contributions to this Special Issue, the paper explores the evolving relationship between cities, urban change and energy policies. Within this broad programme, its particular function lies in addressing three core themes in the following way. Firstly, it confronts studies of current transitions with experiences from the past to illustrate the non-linear, multiple and fluid pathways of urban energy policy in history (see Hughes, 1983; Melosi and Pratt, 2007). Secondly, it highlights the highly political nature of urban energy, both reflecting and reinforcing power configurations and institutional arrangements in the city and beyond (see McFarlane and Rutherford, 2008; Coutard and Rutherford, 2010). Thirdly, it analyses the urban contextualisation of energy policy, in particular the ways in which city politics and urban development shape energy provision and use and, conversely, energy infrastructure systems influence urban life (see Bulkeley et al., 2011a, 2011b).

The paper is structured into three sections. The first section assesses the strengths and weaknesses of various ways of conceptualising change to urban infrastructure systems in the literature. The second section explores the discourses and policies surrounding energy efficiency in Berlin from 1920 to the present, tracing continuities and change across highly diverse political and socioeconomic contexts. The paper concludes with reflections on how an historical study of this kind, framed by concepts of socio-technical change, can advance our understanding of urban and energy transitions.

\section{Conceptualising Change to Urban Infrastructure Systems}

The infrastructure systems which provide cities with energy, water and wastewater services have long become symbols of stability and durability. Designed for decades, embedded in the urban substrata and sustained by complex institutional arrangements, these systems conjure up notions of immobility, obduracy and resilience (Summerton, 1994; Hommels, 2005). Since the 1980s, historians of technology have come a long way in providing explanations for the emergence and subsequent stabilisation of so-called large technical systems (LTS), from their early beginnings in the hands of inventors, entrepreneurs and financiers to the large urban networks familiar to urban landscapes today (Tarr, 1979; Hughes, 1983, 1987; Tarr and Dupuy, 1988; Melosi, 2000). Central to the obduracy of these systems, recent research agrees, are their socio-technical characteristics. A socio-technical system, such as an electricity supply network, comprises not merely a series of physical artefacts and technologies, but also the actors involved in providing and using the services, institutional rules and norms for operating the systems, cultural values and the economic resources to construct and maintain them (Hughes, 1987; Summerton, 1994; Star, 1999). These attributes interact in a 'seamless web' to create, stabilise and, subsequently, sustain a particular socio-technical configuration. Socio-technical systems become thereby particularly prone to path dependency: once established, they prove intrinsically resistant to radical change.

The high degree of path dependency generally attributed to socio-technical systems raises the question of how infrastructure systems change at all. In the literature, there exist various ways of conceptualising sociotechnical change. For the purposes of this 
paper, we are interested in ascertaining how they explain change and what role cities play in their explanations.

\subsection{System Evolution}

Thomas Hughes' model of system evolution, developed around his analysis of the emergence of electricity supply in the US, Germany and Britain, has provided a blueprint for explaining change to large technical systems (LTS) for many historians of technology. In its original form, Hughes' model envisaged a linear process of emergence for a LTS, beginning with invention and development, proceeding through innovation and competition and culminating in consolidation and rationalisation (Hughes, 1983, pp. 14-15). Where radical change occurs at all, it is explained as a result of a 'reverse salient' requiring system adaptation or, in extreme cases, a 'battle of the systems' to decide a new development trajectory. This model of 'stages and ages' has been criticised inter alia for being too linear, for excluding perspectives beyond the main decision-makers and for assuming an inordinate amount of influence by the system builders: individual inventors, engineers and entrepreneurs (Joerges, 1999). The urban dimensions to the historical development of LTS have been the subject of a number of seminal works (for example, Tarr, 1979; Rosen, 1986; Tarr and Dupuy, 1988; Melosi, 2000). This literature has demonstrated the close connectivity between urbanisation processes, urban governance and the emergence of modern urban infrastructures, especially in Europe and North America. These works have provided powerful illustrations of how processes of network construction and expansion were often highly contested and inherently political. They are also valuable for demonstrating the huge relevance of path dependency in explaining how choices made by past generations can limit the options for change today (Melosi, 2005). By virtue of increasing returns on investments, high sunk costs and institutional 'lock-in', socio-technical systems develop self-reinforcing mechanisms which help to explain why subsequent path transformation can prove so difficult (Pierson, 2000; Melosi, 2005). More research is needed, however, on how path dependency works and how change occurs in specific contexts.

\subsection{Reconfiguration}

Social scientists researching present-day socio-technical systems, whilst often drawing on LTS terminology, generally prefer to conceive of change as 'reconfiguration' (Summerton, 1994). This entails the process by which an entrenched configuration of a socio-technical system is opened up ('unbundled') by pressures for change to one or more of its components and becomes restabilised around a new configuration. The principal drivers of change addressed are processes of liberalisation and privatisation of utility services. Socio-technical change is conceived of here not as a transition from one path to another, but as a largely messy, contested and discursive process strongly framed by contexts of action and contingent events. System reconfiguration is the model most commonly referred to by scholars interested in the interdependencies between cities and their infrastructure systems, making it the most spatially sensitive of all explanations of sociotechnical change to date. Characteristic of this literature is a common interest in exploring how cities and their infrastructures co-evolve in the context of shifting geographies of provision and consumption (Guy et al., 2001; Bulkeley et al., 2011b). This is most prominently illustrated by the 'splintering urbanism' thesis developed by Stephen Graham and Simon Marvin (2001), 
who argue that new logics of urban and infrastructure politics are accentuating socio-spatial disparities in utility services.

\subsection{Transitions Analysis and Management}

A third body of work links insight from science and technology studies to innovation studies in order to explain socio-technical dynamics and their management. The principal framework of reference here is the multilevel perspective (MLP) on socio-technical transition (Geels, 2002; Geels and Kemp, 2007). MLP conceptualises change as the result of interaction between three levels: technological niches at the micro level, socio-technical regimes at the meso level and landscapes-or exogenous factors-at the macro level. Characteristic of established socio-technical regimes are incremental processes of reconfiguration, as elements of a system become realigned to accommodate new developments. Radical innovations, by contrast, are generated in technological niches or by shifts in exogenous factors. The MLP framework has been applied in a number of historical case studies to analyse transitions from one stable socio-technical configuration to another. Drawing on this conceptualisation, these and other authors have developed a deliberative application, termed transitions management, to seek ways of promoting desirable transitions (Kemp, 1994; Kemp et al., 1998; Geels, 2002). The transitions school has been subjected to recent criticism for oversimplifying processes of socio-technical transition and playing down important aspects, such as conflicts of interest, social equity, adaptive capacity and discursive representations of change (Smith and Stirling, 2008; Hodson and Marvin, 2010a; Truffer and Coenen, 2012; Bulkeley et al., 2011b). Most significant for our purpose is the lack of sensitivity of MLP (despite the terminology) towards spatial aspects, viewing cities either as homogeneous actors of transition or as locations, or seed-beds, of innovation (Hodson and Marvin, 2010a; Bulkeley et al., 2011b).

From this literature review, a number of strengths of existing research on urban socio-technical transitions of central value to this paper can be readily identified. These include, firstly, the importance of historical trajectories and path dependency to understanding options for change in the future; secondly, the value of conceiving socio-technical transitions as messy and contested process of reconfiguration; thirdly, the attraction of transitions analysis for providing a framework for understanding and promoting socio-technical change. However, a number of other pertinent issues, relating in particular to the 'urban' in socio-technical transitions, have received far less attention to date or are formulated as future research needs (Hodson and Marvin, 2010b; Truffer and Coenen, 2012). The first is how urban transitions (political, socioeconomic or cultural) impact on infrastructure policy. The second is how power relationships-mediated through institutions and infrastructures-condition urban responses to energy or resource needs. The third is how urban infrastructure policy gets caught up in, and shaped by, broader, multi-scalar processes of national or even international politics. These three research gaps are central to the following case study of Berlin.

\section{Electricity for Berlin: The Politics of Energy Efficiency}

Contrary to popular belief, strategic interest in energy efficiency did not first emerge in Europe following the oil crisis of 1973. At different times and in different contexts before then, those responsible for providing 
energy became sensitised to the need to operate their supply systems more efficiently or encourage energy efficiency amongst system users. Again contrary to a common assumption, the history of electricity use in 20th century Berlin (as in many other European cities) was not one of continuous, uninterrupted growth. Electricity consumption and provision fluctuated sharply across the century, with periods of stagnation or decline punctuating the expansion curve (Hellige, 1986; Hessler, 1998). The case study addresses the ways in which infrastructure managers strived to influence the supply of, and demand for, electricity in Berlin from 1920 to the present in response to shifts in the city's political economy. Based on an analysis of strategy documents, policy statements and contemporary publications-including a systematic study of professional journals-it plots continuity and change in policies relating to energy efficiency. Although the perspective studied is restricted to that of infrastructure managers in the city's power utilities and administration, we consider not only the supply side of the equation, but also how they attempted to shape demand for the energy services they provided.

\subsection{Discovering Load Management in Weimar Berlin}

The creation of Greater Berlin in 1920, increasing the city's territory 13 -fold and nearly doubling its population to almost four million, coincided with a dramatic increase in electricity consumption. The city's own power utility Bewag (Berliner Kraft- und Licht-Aktiengesellschaft), responsible for providing around 90 per cent of Berlin's electricity at that time, supplied 338 gigawatt hours (gWh) in 1920. By 1925 this had risen to $662 \mathrm{gWh}$ and by 1929, at the start of the Depression, the figure had doubled again to $1324 \mathrm{gWh}$ (Rehmer, 1934, p. 1; Hughes, 1983, p. 190). Such rapid growth was attributable to the increasing use of electricity not only in industrial production, but also by households. This is reflected in the sharp rise in connection rates to the electricity supply system in Berlin at this time, from 11 per cent of all households in 1922 to 25 per cent in 1925, 60 per cent in 1929 and 76 per cent by 1933 (Czada, 1969, p. 156). With growth curves like these-and looking to even higher levels of electrification in US cities-Bewag officials responded by substantially extending the utility's generating capacity, funded largely with loans from abroad (Bewag, 1928; Rückwardt and Albrecht, 1929). Whilst argued as a logical step to meet growing demand, the investment in new power stations was also designed to reduce the municipal company's dependence on electricity bought from large state-run electricity utilities (Leithäuser, 1959, p. 209; see also Hughes, 1983).

At the same time as Bewag was extending its generating capacity it was discovering the benefits of encouraging the household consumer to use electricity for cooking, heating and other functions (Hessler, 1998). A period of deflation following the stabilisation of the Reichsmark in late 1924 gave rise to concerns that industrial electricity demand would lag seriously behind growth projections. To meet this anticipated shortfall Bewag introduced in 1926 a novel scheme for hire purchase of electrical household appliances in Berlin. Under this scheme, called "Elektrissima", the customer paid for electrical goods in monthly instalments and Bewag paid a small subsidy (between 5 per cent and 10 per cent) to the retailer (Kauffmann, 1927). The scheme also applied to installing electricity to residential properties not yet connected. The utility made no bones about its aim to stimulate demand for its product 
Bewag hopes ... that this easing of payments for the consumer on this unprecedented and improved scale will result in a substantial increase in consumption of electricity (Kauffmann, 1927, p. 83). ${ }^{1}$

Very soon, however, the ability to influence demand for electricity was being used not to increase consumption per se, but to direct it to periods of the day and the year when the power stations were not operating near full capacity. In a major strategy document of 1927, setting out Berlin's electricity supply for the following five years, considerable attention was paid to ways of using prices and advertising to balance the load curves (Bewag, 1928). A special night rate of eight Pfennig per kWH (half the daily rate) was introduced to stimulate night-time consumption. Yet, in the absence of smart meters capable of more refined time-pricing, it was to advertising that the utility looked primarily to "reduce the size of the gap between the three load periods by stimulating additional consumption" (Bewag 1928, p. 10). The advertising campaign discouraged electricity use at peak periods but targeted primarily night uses, such as storage for warm water, street lighting, refrigeration and-intriguingly from today's perspective-batteries for electrical vehicles.

The economic depression of 1929-33 prompted a sharp decline in electricity consumption across Germany, resulting for the first time in problems of underutilisation of generating capacity (Hellige, 1986, p. 126). Bewag's electricity sales fell by nearly 20 per cent from a peak of $1324 \mathrm{gWh}$ in 1929 to 1068 gWh in 1932 (Rehmer, 1934, p. 1). As industrial demand dropped sharply, household consumption took on additional importance, as the following statement by Bewag's chief engineer testifies

If electricity utilities are paying increasing attention to households, this is because the demand from households not only has huge potential but also represents a market which is almost entirely unaffected by shifts in the economy and can therefore provide a valuable basis for the efficiency of power stations in times of economic depression (Rückwardt and Albrecht, 1929, p. 521).

\subsection{Managing Electricity in the Nazi Cause}

On coming to power in January 1933, neither Hitler nor his National Socialist Workers' Party (NSDAP) had a coherent energy policy (Hellige, 1986). In the absence of clear direction from either party or government, various energy interest groups argued their case in terms deemed likely to appeal to one or more strands of the Nazi party's contradictory ideology. Local power utilities, backed by the municipal wing of the NSDAP, pressed the government to limit the expansion of the major power generation companies, playing to anti-capitalist sentiments in the party. Some urged the government to promote new, small technologies, such as combined heat and power or wind energy, in the interest of energy efficiency and national autarky. However, the major power utilities, led by RWE, Preussenelektra and Bayernwerk and backed by a powerful, centralist lobby within the NSDAP, proved far more influential, having a determining influence on the Energy Law of 1935. This law set the institutional framework for centralising and concentrating Germany's energy systems, building up supply capacity around large power plants and regulating prices to stimulate electricity consumption (Hellige, 1986, pp. 138-145).

Programmes to encourage household electricity consumption, such as the "Elekrissima" scheme in Berlin, were continued after 1933, but took on new rationales in response to shifting political 
priorities. The interest of the power utility, Bewag, to balance demand loads by stimulating more electricity use out of peak periods remained, initially, an important motive. The monthly magazine of the utility's NS-run works association, Der Stromkreis, was full of articles in the mid 1930s reporting the apparent success of the electrification programme, sales of electrical appliances and demonstration showrooms. As Martina Hessler has argued, the success of Nazi consumer politics lay less in disseminating new technology and more in helping to stabilise the new regime, creating images of what the modern German-and, in particular, the modern German womanshould be doing (Hessler, 2001). The advertising campaigns addressed consumption not just as a pleasure, but also as a duty. This duty was, in the early years, to support the recovery of the German economy by buying electrical appliances and consuming more electricity. In a series of advertising campaigns - termed, ominously, 'attack waves' by the Bewag's new director Carl KreckeBerliners were called upon to do their bit for the national economic cause

One of the best means of providing the many unemployed with bread and work is comprehensive electrification: there should be no home without electricity, no attics, no stairwells without electrical lighting (advert cited in Lawaczek, 1934, p. 270).

By buying electrical appliances, Germans were encouraged to believe they were serving the Volk and Vaterland. Advertising for electric refrigerators-under the slogan "fight the mould" ("Kampf dem Verderb") argued the need to save food as a means of reducing imports and strengthening national autarky (Hessler, 2001, p. 217).

Equating electricity provision and use with the national interest was reflected not only in advertising campaigns, but also in policy statements and publications elevating electricity, and energy in general, to a public good. Setting electricity up as a service in the common interest (Gemeinnutz), rather than private interest (Eigennutz), was a powerful argumentative tool, buying in to the Nazi ideology of subordination of the individual to the Volk. The common interest at stake was a national resource for all to protect. In a keynote speech in October 1937, the Bewag director Carl Krecke, then head of the Reich Group for Energy, set out this line of Nazi energy policy with reference to its military implications

Any failure of our energy supply could, under certain circumstances, throw into question the success of the efforts and sacrifice of the German Volk in fighting for its economic freedom (Krecke, 1937, p. 380).

\subsection{War and Destruction: Saving Energy to Secure Supply}

The military preparedness of national electricity supply became a political issue soon after the Nazis came to power. In the autumn of 1933, Sub-division IIIB of the Political Central Commission of the NSDAP declared that national defence was "an open wound in the body of the electricity industry" and that making the energy sector "capable of war" had top priority (cited in Leithäuser, 1959, p. 217). In Berlin, in the same year, Bewag responded by setting up an air-raid unit to provide both physical and organisational protection for its plant and workforce from aerial bombardment (Wellmann, 1933).

Energy efficiency to support the war effort became a cornerstone of energy policy in Berlin and in Germany as a whole. Interest in resource efficiency was not new to Nazi planners. The four-year plan of 1936 had been designed to increase national 
self-sufficiency by reducing dependency on imports, such as oil. This had spawned research and investment in a variety of novel technologies to extract material and energy from waste products. For example, Berlin's wastewater utility used motor oil and methane gas derived from wastewater to run its vehicle fleet and heat its buildings (Pallasch, 1937). However, it was only during the war that the more rational use of energy became a dominant theme in policy statements, professional publications and advertising campaigns. On his appointment as Inspector General of Water and Energy in June 1941, Fritz Todt set out his priorities for a reorientation of German energy policy around hydro-electric power, combined heat and power and district heating systems, saving coal reserves for chemical applications and military purposes. ${ }^{2}$

Besides looking to other, more efficientand available-sources of energy, the government introduced an energy saving plan to be implemented by so-called energy engineers, whose job it was to maximise energy efficiency in all large factories. The ultimate military purpose of saving energy was made perfectly clear at the time

This is the value of the energy saving plan: an initiative of the whole Volk, which causes a minimum of inconvenience to restore favourable conditions for producing more weapons (Ruhstrat, 1942, p. 423).

That any energy saved went to serve the armaments industry is reflected in the rapid increase in electricity consumption well into the war. Despite restrictions on street and household lighting and a decline in the city's population following mobilisation, electricity use in Berlin peaked in 1942 at 732 kWh per capita (Leithäuser, 1959, p. 219). Under the slogan "the electricity you save is working for victory", the city's remaining inhabitants were called upon to make yet another sacrifice to ensure the "final victory" (Bezirksamt Charlottenburg von Berlin, 1990, p. 48).

From the winter of $1941 / 42$ onwards, aerial bombardment did cause major, temporary disruptions to electricity distribution in the city, but the power stations themselves were not targeted specifically. Astonishingly, only one of the six power stations in Berlin was bombed-a fact which the later director of the East Berlin power utility, Hans Witte, mischievously put down to the Allies deliberately avoiding damage to plant funded in the 1920s with their own loans (Witte, 1952, p. 1).

Ironically, the only time the whole of the city was without electricity completely was for 24 hours following the Soviet occupation of the city's power stations on 27 April 1945. In the subsequent months, before the arrival of the Allied forces in Berlin, the Soviet authorities dismantled generating plant and transported it-as de facto reparations-to the Soviet Union. They took care to ensure that most of the plant dismantled was in one of the three sectors of the city to be occupied by the Western powers. As a result, the generating capacity of the whole city was reduced by almost one half and of West Berlin by 90 per cent (Brocke and Brüss, 1953, p. 113). The consequence was, inevitably, a major shortage of electricity for the initial post-war years, requiring a strict regime of electricity rationing imposed by the occupying forces. Electricity for lighting was limited to 500 Wh per day and meter plus 50 Wh per person and for cooking to $1.2 \mathrm{kWh}$ per day and meter plus $200 \mathrm{Wh}$ per person (Bewag, 1984). Anyone exceeding these limits was subject to harsh penalties. Nevertheless many did so, incurring some 57,600 fines by the end of 1946. Others resorted to less scrupulous means, such as using an implement-familiarly known as the 'Little Gustav' - to run electricity meters backwards. 


\subsection{Socialist Rationalisation in East Berlin}

The political division of Berlin, in conjunction with the creation of two separate states - the Federal Republic of Germany and the German Democratic Republic (GDR) - in 1949, was pre-empted by the blockade of West Berlin, an event precipitated by the Soviet authorities severing electricity and coal supplies to the western half of the city in June 1948 (Moss, 2009). Parallel to the physical truncation of its power supply networks, the Berlin blockade heralded the organisational division of the city's electricity utility into Bewag (West) and Bewag-East (Merritt, 1968, pp. 172177).

The blockade and subsequent division of the city affected electricity supply in East Berlin far less than in the West. Most of the city's coal reserves were at the time stored at power plants in the eastern half of the city (Merritt, 1968, p. 170). In the early years of division, East Berlin's power stations were able to provide for all its electricity needs, even exporting electricity to the rest of the GDR (Witte, 1952, p. 3). It was with some satisfaction, therefore, that the director of Bewag-East, Hans Witte, announced in 1952

The purpose of a good electricity system must be to provide every inhabitant and every factory with as much electricity as they need to live comfortably or to meet production targets. For this purpose $1000 \mathrm{kWh}$ per annum and capita are regarded as sufficient (Witte, 1952, p. 32).

Such an ambitious consumption target-a third higher than Berlin's peak rate of 1942-was an open declaration of the return to equating modernisation with high electricity consumption. The statement was also intended to publicise one area where East Berlin had a distinct advantage over West Berlin.
However, as generating capacity in East Berlin, and the GDR generally, failed to keep pace with rising consumption levels during the course of the 1950s, the issue of rational energy use re-emerged on the political agenda. As part of the first fiveyear plan a campaign was launched to save electricity which could be redirected to priority sectors of the economy, primarily heavy industry. Similar to the 1940s, energy inspectors (Energiewarte) were sent into factories, analysing energy use, making recommendations and checking whether the targets for energy saving were met. BewagEast rewarded units, such as the 'red shift brigade', for exceeding national targets to save electricity (SED-Betriebsorganisation Bewag, 1975, p. 94). It was argued by those responsible that energy saving was in the common interest and therefore should be easier to implement in a socialist state (Pelka, 1952). Complaints at the lack of support the energy inspectors were receiving and the lack of influence they were having suggest that this assumption was overoptimistic. In practice, the state planning system of electricity supply, based around huge lignite-fired power stations and state-owned utilities, ensured a highly centralised, energy-intensive and supplyoriented system of energy provision with the highest per capita $\mathrm{CO}_{2}$ emissions in the world (Mez et al., 1991, pp. 102-104). By the time the Berlin Wall fell, the East Berlin utility was drawing 77 per cent of its electricity from the GDR grid (Monstadt, 2004, p. 289).

\subsection{Between Expansionism and Environmentalism in West Berlin}

In many ways, West Berlin's experience of electricity availability was the mirror image of the East Berlin story. The truncation of supplies of electricity and coal from the Soviet sector and zone in June 1948 plunged 
West Berlin into an unprecedented supply crisis. In response to the blockade the Allies rapidly established an airlift, flying in essential supplies to the beleaguered city, above all coal to keep the power stations in operation, but also electricity generators. In an impassioned appeal, Councillor Ernst Reuter called on West Berliners to radically reduce their energy use

Every kilowatt hour of electricity, every cubic metre of gas and every litre of water which is taken from our supply pipes costs coal. And new coal can only be provided by air (quoted in Senat von Berlin, 1964, p. 1482).

In the winter of $1948 / 49$, West Berliners had on average only two hours of electricity during the day and two hours at night. Their per capita consumption fell as a result to a mere quarter of East Berlin levels. Following the end of the blockade on 12 May 1949, West Berlin was able to reach a number of agreements on the delivery of electricity from East Berlin. However, none of these proved reliable. In March 1952, Bewag-East precipitated the termination of all electricity supplies to West Berlin. From then until German reunification West Berlin was to remain an 'electricity island', cut off from the national and regional grids of both West and East Germany (Merritt, 1968; Varchmin and Schubert, 1988; Bewag, 1991).

It is against this prolonged and bitter experience of system vulnerability that West Berlin's subsequent strategy of expanding its electricity generating capacity as much and as fast as possible needs to be understood. It was no coincidence that one of the first acts of Councillor Reuter following the end of the blockade was to call for the reconstruction of the city's main power station, Kraftwerk West, as a deterrent against similar Soviet interventions in the future (Senat von Berlin, 1964, p. 1554). By 1952, this flagship power station had been restored to a capacity of $268 \mathrm{MW}$, already providing the lion's share of the total $382 \mathrm{MW}$ at West Berlin's disposal (Brocke and Brüss, 1953, p. 114). By early 1955, within an extraordinarily short period of time, Bewag-West had become self-sufficient in electricity generation, largely thanks to credits to fund capital investments from the European Recovery Programme.

As West Berlin's economy recovered, electricity consumption in the city soared. In 1952 it stood at a lowly 1000 gWh but increased sharply and continuously to approximately $10,500 \mathrm{gWh}$ by 1990 (Ziesing, 1985, p. 236; Bewag, 1991, p. 8). This increase in electricity consumption was linked not only to economic recovery, but also to sales of electrical goods. Bewag reintroduced the "Elektrissima" hire purchase scheme to great effect. By 1966, the scheme had half a million customers on its books and had made sales totalling 170 million DM (Bezirksamt Charlottenburg, 1990 , p. 46). That Bewag-West was keen to encourage household electricity consumption is indicative of its confidence in being able to generate enough power to meet demand. It can also be attributed to the fact that rising consumption levels brought increased revenue and profits for the company and the West Berlin government, the majority shareholder.

There is no indication that Bewag-West seriously considered saving energy and curbing demand as a way of helping to secure electricity supply in its precarious insular situation. It continuously defied political pressure to promote demand-side management and renewable energies (Monstadt, 2007, p. 329). This is all the more surprising since the utility-by virtue of being separated from national grids-had to build up reserves of generating capacity far in excess of conventional levels and had to rely on expensive imported coal. On several occasions, capacity was pushed to the limit, as in 
the summer of 1982 following a fire at one of the power stations and during the harsh winter of $1986 / 87$.

It took a number of protests against the construction of new power stations in the city together with the oil crisis in 1973 for Bewag-West to reconsider its expansionist strategy, albeit in a modest way (Monstadt, 2004 , pp. 280ff). The company began advising on energy saving and alternative forms of energy, such as heat pumps and solar collectors. More effort was put into expanding the district heating network, exploiting the central location of many of its co-generating power stations. By 1988, 17 per cent of heating in West Berlin was provided by district heating systems, compared with eight per cent in West Germany (Varchmin and Schubert, 1988 , p. 24). However, the city authoritiesechoing the utility-were sceptical about the possibilities of saving electricity

reducing peak loads by means of efficient and rational electricity use are-given the consumption conditions in Berlin-barely possible (Presse- und Informationsamt, 1978, p. 10).

A radical policy change was heralded in 1989, with the election of the city's first social democratic-green coalition, which created an energy task force to promote more efficient power stations, renewable energies and demand-side management and, in 1990, a new state Energy Law setting out an institutional framework for energy planning (Monstadt, 2007, p. 329).

\subsection{Post-1990 Reconfiguration}

However, within months of the red-green coalition coming to power, the Berlin Wall fell, causing the city's emergent energy policy to be overshadowed by the pressing requirements to reconnect the energy systems of East and West Berlin, amalgamate the two power utilities, link the West Berlin network to the national grid and modernise the East Berlin network (Bewag, 1991; Monstadt, 2004, pp. 298ff). Parallel to these Berlin-specific tasks, responses were needed to broader drivers of change in Germany: the liberalisation of electricity markets and privatisation of electricity utilities, political pressure for ecological modernisation and the viability of new energy technologies (Monstadt, 2007). Policies to promote energy efficiency in a reunified Berlin were framed by the opening up of the city's electricity market to competition, the emergence of new actors providing energy services and, in 1997, the complete privatisation of Bewag.

The conservative-social democratic government formed in 1990 pursued the energy policy path set out by its red-green predecessor, but with far less enthusiasm. The Energy Concept for Berlin of 1994 targeted a 25 per cent reduction in $\mathrm{CO}_{2}$ emissions between 1990 and 2010 and included an energy-saving action plan, covering housing, public buildings, transport, energy services and renewable energies (Monstadt, 2004, pp. 313-314). However, the city government was not prepared to force Bewag to prioritise energy efficiency. In the absence of serious regulatory pressure on its own utility, the Berlin government resorted to public funding for projects planned under the Energy Concept. When the city ran into massive debt from 1992 onwards, funding for these projects dropped sharply. Henceforth, the city relied increasingly on private contractors to implement its energysaving programmes- to limited effect. One of the few projects to enjoy modest success was a scheme to increase energy efficiency and reduce energy costs in public buildings by pooling lucrative and less lucrative buildings in contracts to private energy service companies. Between 1995 and 2005 some 500 buildings were renovated under the scheme, but this fell well below the original target (Monstadt, 2007, p. 331). In 2010, 
under a social democratic-socialist party coalition, the city government adopted a new Energy Concept targeting a 40 per cent reduction in $\mathrm{CO}_{2}$ emissions by 2020 . The city aims to set new standards for sustainable urban energy policy in promoting greater energy efficiency and renewable energies (Senatsverwaltung für Wirtschaft, Technologie und Frauen, 2011, p. 4). The strong path dependency of Berlin's energy policy following reunification (Monstadt, 2004, pp. 493-496) cautions, however, against overoptimistic expectations of a strategic shift in direction.

\section{Conclusions}

This paper set out to challenge oversimplistic notions of energy transitions in cities as straightforward shifts from a supplyoriented, fossil-based system to a lowcarbon, energy-efficient one. Rather than following a single technological innovation or focusing on a particular energy transition, we took a long-term perspective on the shifting context of energy efficiency in Berlin in order to illustrate how urban transitions can influence energy policy and practice. Given Berlin's history of repeated and radical regime change across the 20th century, our interest lay in revealing what impact different political regimes and socioeconomic circumstances had on the way energy efficiency was discussed and pursued. This case study was set in the context of recent research on socio-technical transitions in cities with a view to identifying research gaps which it could address. We conclude the paper by summarising how the findings from the Berlin case build on, and add to, this knowledge.

Firstly, the Berlin case reveals that energy efficiency strategies have a long pedigree, beginning well before the 1973 oil crisis, but that they were highly fluid, emerging in situations of perceived or feared electricity shortage only to disappear again at times of adequate supply capacity. This provides an interesting lesson in the non-linearity and expediency of shifts in socio-technical configurations. The predominant concern was always for the effective operation of the electricity supply networks, rather than the efficient use of energy. Only when the latter contributed to the former did it enjoy (brief) political support. The persistence of this supply-oriented logic across democratic, dictatorial and state-socialist regimes illustrates the importance of taking a long-term perspective on potential path dependencies when analysing energy transitions. It also suggests that any future energy transition which challenges this dominant logic is likely to be messy and contested, rather than neat and straightforward.

Secondly, the Berlin case illustrates how efforts to shape demand for electricity can be put to very different purposes, depending on the context. The hire purchase scheme "Elektrissima" was actively promoted under three different political regimes. It was introduced in Weimar Berlin initially to support electrification and was subsequently refined as an instrument of load management to direct electricity use to off-peak periods. During the Depression, it became used to offset a drop in demand by industry and, under the Nazis, to stimulate job creation in the electrical industry. When power generation systems were unable to meet demand, in particular during the war and afterwards in both West and East Berlin, advertising, public appeals and even fines were used to encourage lower electricity consumption. Together, these instances of demand management illustrate the high degree of context-dependency of Berlin's energy efficiency strategies. They are indicative of the multiple geographies of such contexts. As the Berlin example illustrates, the spatial factors influencing the development 
of an electricity supply system are not just material, technical or environmental, as might be expected, but are often also social, economic and political. They can also span multiple scalar levels, from the local to the global. Importantly, such spatial factors act not simply as a contextual backdrop for energy policy, but as constitutive elements of change and continuity to urban energy systems.

Thirdly, the political nature of energy policy has been a leitmotif of the case study. Efforts to promote energy efficiency in Berlin have been inextricably tied up in, for instance, the volkisch ideology of the Nazi regime, the geo-politics of post-war division, the liberalisation of energy markets in Europe and the global discourse on climate change today. Berlin's electricity supply system was, however, not simply a product, but also a medium of the city's political economy. It was actively enrolled in supporting important political objectives of each regime, whether the modernisation agenda of Weimar Berlin, national autarky in the 'Third Reich', consolidating socialism in the GDR or greening the economy in a reunified Berlin. A good example is the diversity of political motives underpinning the quest for 'energy security' under different regimes. In 1920s Berlin, energy security was about providing adequate generating capacity to meet spiralling demand. To the Nazi regime, it meant inter alia protecting energy infrastructures from aerial bombardment. To West Berliners during and after the blockade of 1948/49, it meant being selfsufficient in electricity generation. Today, energy security covers issues ranging from responsiveness to climate change to protection from terrorist attacks. Deconstructing the notion of energy management as being something politically neutral is crucial to understanding what role power relations can play in advancing and constraining socio-technical transitions.
To conclude, Berlin's historical experience of energy efficiency suggests that we need to pay greater attention in future research to how different components of a socio-technical system change at different speeds and different times. We also need to consider more closely how socio-technical transitions are constructed by different actors, what diverse motives they embody and whose interests they serve. Above all, we require a better grasp of the multiple geographies of socio-technical transitionspolitical, socioeconomic and cultural, as well as material, technical and environmentaland how they shape, and are shaped by, energy policy.

\section{Funding}

This research received no specific grant from any funding agency in the public, commercial or notfor-profit sectors.

\section{Notes}

1. All translations of original quotations in German are by the author.

2. Speech by F. Todt, Deutsche Technik, 9, p. 390 .

\section{References}

Berliner Kraft- und Licht(Bewag)-Aktiengesellschaft (Ed.) (1984) 100 Jahre Strom für Berlin: Ein Streifzug durch unsere Geschichte in Wort und Bild 1884-1984. Bewag, Berlin.

Berliner Kraft- und Licht(Bewag)-Aktiengesellschaft (Ed.) (1991) Strom für Berlin: Von der Spaltung zur Wiedervereinigung. Bewag, Berlin.

Berliner Städtische Elektrizitätswerke Akt.-Ges. (Bewag) (1928) Zur Zukunft der Berliner Elektrizitäts-Versorgung. Bewag, Berlin.

Bezirksamt Charlottenburg von Berlin (1990) Stadt unter Strom: Zur Kulturgeschichte der Elektrifizierung. Heimatmuseum Charlottenburg, Berlin.

Brocke, W. and Brüss, L. (1953) Die Berliner Energieversorgung, in: Institut für Raumforschung, 
Köln (Ed.) Die unzerstörbare Stadt: die raumpolitische Lage und Bedeutung Berlins, pp. 111118. Berlin: Carl Heymanns Verlag.

Bulkeley, H. and Betsill, M. M. (2003) Cities and Climate Change: Urban Sustainability and Global Environmental Governance. London: Routledge.

Bulkeley, H., Broto, V. C. and Maassen, A. (2011a) Governing urban low carbon transitions, in: H. Bulkeley, V. C. Broto, M. Hodson and S. Marvin (Eds) Cities and Low Carbon Transitions, pp. 29-41. Abingdon: Routledge.

Bulkeley, H., Broto, V. C., Hodson, M. and Marvin, S. (Eds) (2011b) Cities and Low Carbon Transitions. London: Routledge.

Coutard, O. and Rutherford, J. (2010) Energy transitions and city-region planning: understanding the spatial politics of systemic change, Technology Analysis \& Strategic Management, 22(6), pp. 711-727.

Czada, P. (1969) Die Berliner Elektroindustrie in der Weimarer Zeit: Eine regionalstatistischwirtschaftshistorische Untersuchung. Berlin: Colloquium Verlag.

Geels, F. W. (2002) Technological transitions as evolutionary reconfiguration processes: a multi-level perspective and a case-study, Research Policy, 31, pp. 1257-1274.

Geels, F. W. and Kemp, R. (2007) Dynamics in socio-technical systems: typology of change processes and contrasting case studies, Technology in Society, 29(4), pp. 441-455.

Graham, S. and Marvin, S. (2001) Splintering Urbanism: Networked Infrastructures, Technological Mobilities and the Urban Condition. London: Routledge.

Guy, S., Marvin, S. and Moss, T. (Eds) (2001) Urban Infrastructure in Transition: Networks, Buildings, Plans. London: Earthscan.

Hellige, H. D. (1986) Entstehungsbedingungen und energietechnische Langzeitwirkungen des Energiewirtschaftsgesetzes von 1935, Technikgeschichte, 53(2), pp. 123-154.

Hessler, M. (1998) 'Do companies know what women want?': the introduction of electric domestic appliances during the Weimar republic. Ann Arbor, MI: Mpublishing.

Hessler, M. (2001) 'Elektrische Helfer' für Hausfrau, Volk und Vaterland: Ein technisches Konsumgut während des Nationalsozialismus, Technikgeschichte, 68(3), pp. 203-229.
Hodson, M. and Marvin, S. (2010a) Can cities shape socio-technical transitions and how would we know if they were?, Research Policy, 39, pp. 477-485.

Hodson, M. and Marvin, S. (2010b) World Cities and Climate Change. Maidenhead: Open University Press.

Hodson, M., Marvin, S., Bulkeley, H. and Broto, V. C. (2011) Conclusion, in: H. Bulkeley, V. C. Broto, M. Hodson and S. Marvin (Eds) Cities and Low Carbon Transitions, pp. 198-202. Abingdon: Routledge.

Hommels, A. (2005) Studying obduracy in the city: toward a productive fusion between technology studies and urban studies, Science, Technology, \& Human Values, 30(3), pp. 323-351.

Hughes, T. P. (1983) Networks of Power: Electrification in Western Society, 1880-1930. Baltimore, MD: The Johns Hopkins University Press.

Hughes, T. P. (1987) The evolution of large technological systems, in: W. E. Bijker, T. P. Hughes and T. Pinch (Eds) The Social Construction of Technological Systems: New Directions in the Sociology and History of Technology, pp. 51-82. Cambridge, MA: The MIT Press.

Joerges, B. (1999) High variability discourse in the history and sociology of large technical systems, in: O. Coutard (Ed.) The Governance of Large Technical Systems, pp. 258-290. London: Routledge.

Kauffmann, R. (1927) Das Abzahlungsmodell des Bewag, Elektrizitätswirtschaft, 26(427), pp. 81-83.

Kemp, R. (1994) Technology and the transition to environmental sustainability: the problem of technological regime shifts, Futures, 26(10), pp. 1023-1046.

Kemp, R., Schot, J. P. and Hoogma, R. (1998) Regime shifts to sustainability through processes of niche formation: the approach of strategic niche management, Technology Analysis \& Strategic Management, 10(2), pp. 175-195.

Krecke, C. (1937) Nationalsozialistische Gestaltungswillen in der Energiewirtschaft, Der Stromkreis, 4(11), pp. 378-380.

Lawaczek, F. (1934) Zur Neuordnung der Elektrowirtschaft, Deutsche Technik, 2, pp. 270-275. 
Leithäuser, J. G. (1959) Die unsichtbare Kraft: Roman der Elektrizität. Berlin: Safari-Verlag.

McFarlane, C. and Rutherford, J. (2008) Political infrastructures: governing and experiencing the fabric of the city, International Journal for Urban and Regional Research, 32, pp. 363-374.

Melosi, M. (2000) The Sanitary City: Urban Infrastructure in America from Colonial Times to the Present. Baltimore, MD: The Johns Hopkins University Press.

Melosi, M. (2005) Path dependence and urban history: is a marriage possible?, in: D. Schott, B. Luckin and G. Massard-Guilbaud (Eds) Resources of the City: Contributions to an Environmental History of Modern Europe, pp. 262275. Aldershot: Ashgate.

Melosi, M. and Pratt, J. (2007) Energy Metropolis. Pittsburgh, PA: University of Pittsburgh Press.

Merritt, R. L. (1968) Political division and municipal services in postwar Berlin, in: J. D. Montgomery and A. O. Hirschman (Eds) Public Policy, 17, pp. 165-198. Cambridge, MA: Harvard University Press.

Mez, L., Jänicke, M. and Pöschk, J. (1991) Die Energiesituation in der vormaligen DDR: Darstellung, Kritik und Perspektiven der Elektrizitätsversorgung. Berlin: Edition Sigma.

Monstadt, J. (2004) Die Modernisierung der Stromversorgung: Regionale Energie-und Klimapolitik im Liberalisierungs-und Privatisierungsprozess. Wiesbaden: VS Verlag für Sozialwissenschaften.

Monstadt, J. (2007) Urban governance and the transition of energy systems: institutional change and shifting energy and climate policies in Berlin, International Journal of Urban and Regional Research, 31(2), pp. 326-343.

Monstadt, J. (2009) Conceptualizing the political ecology of urban infrastructures: insights from technology and urban studies, Environment and Planning A, 40, pp. 1924-1942.

Moss, T. (2009) Divided city, divided infrastructures: securing energy and water services in post-war Berlin, Journal of Urban History, 35(7), pp. 923-942.

Pallasch, O. (1937) Reinigung und Verwertung gewerblicher Abwässer in Berlin, GesundheitsIngenieur, 60(21), pp. 334-337.

Pelka, G. (1952) Weg zur Einsparung von Elektroenergie, Energietechnik, 2(5), pp. 130-135.
Pierson, P. (2000) Increasing returns, path dependence, and the study of politics, The American Political Science Review, 94(2), pp. 251-267.

Presse- und Informationsamt des Landes Berlin (Ed.) (1978) Energie 1 (Grundfragen der Energiesicherung). Presse- und Informationsamt des Landes Berlin.

Rehmer, M. (1934) Der Ausbau und die Betriebsführung der Bewag seit dem Jahre 1924, Sonderabdruck aus der Zeitschrift des Vereins deutscher Ingenieure, 78(18), pp. 539-545.

Rosen, C. M. (1986) Infrastructural improvement in nineteenth-century cities: a conceptual framework and cases, Journal of Urban History, 12(3), pp. 211-256.

Rückwardt, H. and Albrecht, C. (1929) Der gegenwärtige Stand der Elektrizitätsversorgung von Haushaltungen in Berlin, Elektrizitätswirtschaft, 28, pp. 521-525.

Ruhstrat, O. (1942) Wir sparen Energie, Deutsche Technik, 10, pp. 423-424.

SED-Betriebsorganisation Bewag (Ed.) (1975) Unsere Kraft: Betriebsgeschichte der Bewag, 2, Teil 1949-1961. Bewag, Berlin.

Senat von Berlin (1964) Berlin: Quellen und Dokumente 1945-1951. Berlin: Heinz Spitzing Verlag.

Senatsverwaltung für Wirtschaft, Technologie und Frauen (Ed.) (2011) Energiekonzept 2020. Berlin.

Smith, A. and Stirling, A. (2008) Socio-ecological resilience and socio-technical transitions: critical issues for sustainability governance. Working paper, STEPS (Social, Technological and Environmental Pathways to Sustainability) Centre (http://www.steps-centre.org/PDFs/ STEPS\%20Working\%20Paper_Transitions. pdf; accessed 4 May 2011).

Star, S. L. (1999) The ethnography of infrastructure, American Behavioural Scientist, 43(3), pp. 377-391.

Summerton, J. (1994) Introductory essay: the systems approach to technological change, in: J. Summerton (Ed.) Changing Large Technical Systems, pp. 1-21. Colorado, CO: Westview Press.

Tarr, J. A. (Ed.) (1979) Special issue: the city and technology, Journal of Urban History, 5, pp. 275-408.

Tarr, J. A. and Dupuy, G. (Eds) (1988) Technology and the Rise of the Networked City in 
Europe and America. Philadelphia, PA: Wellmann (1933) Vom Luftschutz der Bewag, Temple University Press.

Truffer, B. and Coenen, L. (2012) Environmental innovation and sustainability transitions in regional studies, Regional Studies, 46(1), pp. 1-21.

Varchmin, J. and Schubert, M. (1988) Stromerzeugung und Elektrizitätswirtschaft: Aufstieg der Elektroindustrie-das EnergiegesetzEnergieinsel Berlin. Museum für Verkehr und Technik, Berlin. Der Stromkreis, 1(1), pp. 15-17.

Witte, H. (1952) Die gegenwärtige und zukünftige Stromversorgung Berlins, Energietechnik, 2, pp. 1-4 and 32.

Ziesing, H.-J. (1985) Strukturelle und sektorale Entwicklung des Energieverbrauchs in Berlin (West). Wochenbericht, 52, Deutsches Institut für Wirtschaftsforschung, pp. 227-238. 